\title{
Effective Accountability Mechanisms Overseeing Corrections in Australia and Beyond: Are Ombudspersons a Vital Element in the Rule of Law or a Forlorn Hope?
}

Craig W. J. Minogue

$\mathbf{B}^{\text {eing inspired by the work of Michel Foucault, I take a personally }}$ Bengaged and personally responsible subjective position on the human and social situation that I believe is terribly wrong and intolerable. Garry Gutting (1994, p. 10) wrote that Michel Foucault's genealogies "begin from his perception that something is terribly wrong in the present" and they are aimed at an understanding of what is "intolerable in the present". Michel Foucault defended his scholarship as being one which was situated in the modality of the specific intellectual who took a subjective stand from within the power relationships which were being examined, rather than presuming that one can stand outside power relations and objectively make pronouncements from an academic high-ground in relation to the rightness or wrongness of the practices being observed. A specific intellectual is a person who works "not in the modality of the 'universal', the 'exemplary', the 'just-and-true-for-all', [rather they work] within specific sectors, at the precise points where their own conditions of life or work situate them" (Foucault, 1980, p. 126). Of Michel Foucault's specific intellectual, Todd May (1993, pp. 6-7) says:

...rather than standing above or outside their society, 'specific intellectuals' are immersed within it. They cite, analyse, and engage in struggles not in the name of those who are oppressed, but alongside them, in solidarity with them, in part because other's oppression is often inseparable from their own. This type of intervention allows them to embrace the oppression that 'universal intellectuals' used to analyse and to understand it better than the latter did, because rather than pronouncing on the fate of others from on high or outside, they carry with them an experience of the kind that belongs to the oppressed themselves.

The specific sector and the precise point where my conditions of life and work situate me are the prison as I have been a prisoner since 1986 . The philosopher Gilles Deleuze said of Michel Foucault's work, that it demonstrated its empathy with the subject, by not talking for the subject, and that there was an inherent indignity associated with speaking for 
others which results when intellectuals take a universal and objective view from the outside of power-relations (in Foucault, 1977, p. 209). I feel this indignity when my experience is spoken about by others who stand on high and view the situation. Thus, in this paper, I will be speaking for myself and about my lived experience.

The sociological circumstances of prisoners in Victoria, Australia, are much the same around the country, and no doubt similar to those around the industrialised world with poor levels of education and unemployment being common. On reception into prison in Victoria the highest level of education attained or self-reported by prisoners as being attained was as follows:

- $\quad 2 \%$ have a tertiary or other post-secondary education;

- $\quad$ less than $1 \%$ have a trade qualification;

- $\quad 3.9 \%$ have completed secondary schooling;

- for $1.5 \%$ the highest level of their education was primary schooling;

- the majority, $89.2 \%$ have a partial secondary education; and

- $\quad 67.3 \%$ were unemployed (Department of Justice / Corrections Victoria, 2010 pp. 37-38). ${ }^{1}$

Issues of mental health are also important when considering the abilities of prisoners seeking re-dress for what they feel is an abuse of power. Defending oneself against an abuse of power requires a level of educational, legal, social and cultural literacy, which many prisoners do not possess. If professional assistance from lawyers is not available, then prisoners are left to their own devices to seek redress for any wrong they perceived as having been done to them. Men and women in custody, and their families, feel the impact of governmental control over every aspect of their lives, more than any other people in the community. Whether a person in custody does, or does not, receive clothing, food or water, is a matter that is at the whim of prison staff.

In my experience as a prisoner since 1986, the major problem which impacts on the lives of prisoners is that prison staff and management do not understand the law as it relates to corrections or proper administrative decision-making processes, and they operate by a 'might is right' modality of their individual will. This might is right modality is supported by instruments of restraint, pain compliance techniques, physical and chemical weapons of restraint, firearms, electro-shock and striking weapons (Minogue, 2005). 
In Victoria, and other states in Australia, the Ombudsman's Office is effectively the sole accountability mechanism for prisoners, and "of the 4,248 complaints about Justice, 3,177 (75 per cent) related to prison" (Victorian Ombudsman, 2014). Prisoners are excluded from federal human rights protection by law, and state level human rights are decision-making considerations and not justiciable rights as such (Minogue v Human Rights and Equal Opportunity Commission [1998]; (1999); Minogue v Williams (2000); Minogue v Australia 2004).

According to the Victorian Ombudsman's most recent Annual Report (2014), prisoners complain to the Ombudsman about:

- $\quad$ Prisoner health services (15\%)

- $\quad$ Prisoner property (7\%)

- Prison buildings and facilities (5\%)

- $\quad$ Prisoner placement and location (4\%)

- Delays in complaint handling in prisons (4\%)

- $\quad$ Prisoner visits (3\%)

- Prisoner funds $(3 \%)$

- Prisoner telephone access/services (3\%)

- $\quad$ Prison food $(3 \%)$

- The right to humane treatment when deprived of liberty $(3 \%)$

Without the appropriate level of educational, legal, social and cultural literacy to properly pursue a matter of complaint themselves prisoners must rely on an effective administrative and human rights accountability mechanism acting in good faith. By law, the Ombudsman's Office in Victoria fulfils the role of such a mechanism, so it needs to be asked, is that Office an effective oversight mechanism? Such a question could also be asked in other jurisdictions where Ombudpersons are said to provide oversight for the administration of prisons.

I raised the issue of the effectiveness of the Ombudsman's Office with the Committee of the United Nations High Commissioner for Human Rights (UNHCHR) in Minogue v. Australia 2004. I argued that when a prisoner makes a complaint to the Ombudsman's Office most were not taken seriously and not investigated or properly dealt with. I supported my claim that the Ombudsman's Office was not effective as an independent complaints handling authority with primary evidence from lawyers and community groups. 
Gabriel Kuek (2002), who had been a lawyer for 20 years at the time, and who had acted for numerous people in respect of complaints to the Victorian Ombudsman concerning alleged misconduct and omissions on the part of Victorian public servants, predominantly the police, wrote to the UNHCHR and advised:

Save for one instance, my dealings with the Ombudsman's Office have been discouraging. I have found that Office to be lacking in its investigative and remedial functions. At times, I concluded that Office was more eager to explain and justify alleged misconduct than in conducting a fair and balanced inquiry into the matters my clients complained of. It is my opinion that lodging a complaint with the Victorian Ombudsman's Office is likely to prove futile and have advised my clients so.

Richard Edney (2002), an academic and lawyer wrote to the UNHCHR and said:

In relation to the investigation of complaints by the Ombudsman it has been our experience that the notion of 'investigation' is somewhat misleading. Indeed, it seems that the practice of that Office is to deal with matters on the paperwork alone. In our view, this does not really amount to a proper investigation.

Sam Biondo (2002) from the Fitzroy Legal Service, the most prominent legal service in Melbourne, states in his submission to the UNHCHR that:

Like many others, we have at times found dealing with the Office of the Ombudsman to be an extremely frustrating experience; for example it is a rare occurrence for a complaint against a police officer to be substantiated. We do not attribute this lack of success in many instances to a deficiency with the registered complaint. It is even more frustrating utilizing the Office of the Ombudsman in relation to a prison issue.

Furthermore, the Office relies too heavily on the voluntary co-operation of police and prison authorities. We believe that these authorities are unlikely to fully assist with investigations where an adverse finding is the likely outcome. There are also important issues with the Ombudsman's emphasis 
on handling many prisoner complaints through liaison rather than through investigation. . . A Apart from the sorts of delays incurred by individual complaints, the time lags between certain incidents and the conclusion of an Ombudsman's report can be lengthy [and] ... domestic remedies such as the State Ombudsman, [are] of significantly limited value and of no practical use.

Cathy Smith (2002), who was then the Chief Executive Officer of the Victorian Council of Social Services (VCOSS), which is the peak advocacy and policy research agency for the community sector in Victoria and which was established in 1946, states in a letter to the UNHCHR that:

The issues brought to your attention by the Victorian Fitzroy Legal Service would also be of concern to VCOSS as their very existence would seem to imply that a fair share of the community's resources and services and the treatment of all people as equal is being compromised by:

- the lack of adequate resources to investigate the matter properly;

- the tendency to liaise rather than investigate complaints;

- the extremely low rate of substantiated complaints in relation to prisoner complaints; and

- the inability of the Ombudsman to enforce a remedy.

The Committee found the Ombudsman's Office was not an effective remedy and I did not have to exhaust that avenue of complaint before I could bring a matter to the international community under an instrument like the First Optional Protocol of the International Covenant on Civil and Political Rights (]ICCPR) (Minogue v Australia, 2004, para.6.3).

As Table 1 indicates (see below), primary evidence of the ineffective nature of the Ombudsman in Victoria is found in the low rate of substantiated complaints from prisoners. In 2002 and 2003, I published articles questioning how substantiation rates of prisoners complaints could be so low (Minogue, 2002; Minogue, 2003). For the Annual Report 2003/04, and subsequent Reports, the details of the numbers of complaints formally investigated and substantiated from prisoners have not be included. 
Table 1: Prisoner Complaints, Investigations and Findings by Year

\begin{tabular}{l|c|c|c}
\hline Year & \# of Complaints & $\begin{array}{c}\text { Investigations } \\
\text { (\#) }\end{array}$ & $\begin{array}{c}\text { substantiated } \\
\text { complaints(\#) }\end{array}$ \\
\hline $1997 / 98$ & 787 & 1 & 1 \\
\hline $1998 / 1999$ & 771 & 0 & 0 \\
\hline $1999 / 2000$ & 562 & 1 & 1 \\
\hline $2000 / 2001$ & 746 & 1 & 1 \\
\hline $2001 / 2002$ & 699 & 1 & 1 \\
\hline $2002 / 2003$ & 673 & 1 & \\
\hline
\end{tabular}

Source: Ombudsman, Victoria, 2007.

How does the Ombudsman in Victoria compare to other jurisdictions? In England and Wales, for 2010/11, the Prisoners and Probation Ombudsman (PPO) accepted for investigation, 50 percent of the complaints made (Seneviratne, 2012). The lowest acceptance rate of complaints by the PPO was 36 percent in 2007/08 (ibid). In Scotland, for 2010/11, the Scottish Public Services Ombudsman accepted 29 percent of prisoner complaints for investigation (ibid). In Northern Ireland, for 2010/11, the Prisoner Ombudsman for Northern Ireland accepted 46 percent of complaints for investigation (Seneviratne 2012). Of the 476 complaints made to the Prison Commissioner for North Rhine-Westphalia Germany in 2011/12, only 25 were found to be ineligible and not accepted for investigation (Carl, 2013, p. 370). The Ombudsman in Victoria, accepts less than 1 percent of complaints for investigation.

The one percent of complaints that are accepted for formal investigation and sustained, are often used to publicly discredit prisoners' complaints. For example, a prisoner attempted to redeem a Mars Bar as part of a 'get one free' promotion. The Prisoners Shop, a registered business, refused saying: "We don't run a charity here!" The prisoner complained that the Shop was a retailer who sold the Mars Bar and it said on the packet that if it was a winner that the retailer would redeem the wrapper for a free bar, so why are prisoners excluded? The Mars Bar wrapper complaint, which was referred to by the media as 'the chocolate bar incident', was officially investigated and it was the one token complaint sustained for that year, and the details 
of it were highlighted in the Annual Report 2001/02 of the Ombudsman's Office. This case was reported in a screaming headline that "Crims take the cake" (Kelly, 2003, p. 9). The opposition police and corrections spokesman said: "It is ridiculous the Ombudsman was being tied up with such [trivial] complaints. The prison system seems to be operating as a joke in this state" (Kelly, 2003, p. 9). What is ridiculous is that 'the chocolate bar incident' is the one complaint that the Ombudsman's Office chose to formally investigate and substantiated from the 699 complaints from prisoners that year.

In a second case, a prisoner bought potato chips from the Prisoners Shop over a 12-month period. In the chips there were small children's toys. The man saved the toys and wanted to send them out to his children. When the man went to post a large envelope with the toys a particularly nasty guard said it was not allowed and, in fact, he had to put the toys in his property box or throw them away.

I helped the man write a letter to the Ombudsman's Office complaining that the administrative decision not to allow the man to send out his property to his children was unreasonable considering the absentee parenting efforts of this man. The Ombudsman's Office formally investigated and sustained this complaint, the only one for that year. Then the Ombudsman Annual Report for that year detailed the case and it was reported in the media under the headline "Toy ban chipped" (Herald Sun, 2005). It was reported that there were 3961 complaints to the Ombudsman's Office in 2003/04 from all areas under the jurisdiction (no further breakdown was provided), and this is the one which is publicized and reported by the media, the one about "a prisoner with a taste for potato chips" (ibid). The issue here was not the man's liking of potato chips, but rather unreasonable administrative decision-making about prisoner property and abuse of power that negatively impacted upon a man's right to maintain contact with and emotionally support his children from prison. Complaints from prisoners are misrepresented and ridiculed in the media, and thus devalue the need for administrative and human rights accountability mechanisms overseeing corrections.

To understand how effective the Ombudsman's Office in Victoria is in relation to complaints from prisoners about corrections, it will be illustrative to look at another area where the Ombudsman has jurisdiction as an agency of accountability. The Ombudsman's Office also has the jurisdiction over the Victoria Police and in the Annual Report 2000/01, the Ombudsman's Office reveals that it investigated 1,575 specific complaints against police, 
and the net formal investigation and substantiation rate was 21 percent (Victorian Ombudsman, 2001, pp. 26-27). This rate is much better than the one for investigation and substantiation of prisoner's complaints, which is less than 1 percent.

A complaint to the Ombudsman's Office is so ineffective that many prisoners view it as not being worth the time and effort. The ineffectiveness of the Ombudsman's Office is also widely known in the community, for example:

Kate Lawrence is a lawyer with the North Melbourne legal centre, which represents many inmates. "The Ombudsman's Office is terribly ineffectual", she says. "Essentially what they do is go to the people you have complained about, get their story and say, there is your answer. You already knew that. The fact that nothing happens can exacerbate frustrations. In terms of teeth, the Ombudsman is a gummy shark. Prisoners don't view it as a serious option" (Mottram, 2001, p. 3).

Another lawyer said:

It is understandable that so far as my clients are concerned, the Office of the Ombudsman is viewed as a waste of space. If you are bashed in a police station and there are no witnesses you are wasting time going to the Ombudsman (ibid).

It is thought by some to be a 'waste of time' complaining about the police, but 21 percent of complaints about the police are substantiated, whereas historically the Ombudsman's Office conducts one investigation and sustains one complaint a year from prisoners. It is not hard to imagine that many of the people who make complaints about the police are for the most part in a similar social situation as people who make complaints about prison officers, and the complaints about the abuse of power are similar in the case of police and prison officers. Complaints about police officers have a substantiation rate which is 20 times higher than that of complaints against prison officers.

Unreasonable delay is also a significant issue undermining the effectiveness of the Ombudsman's Office as a remedy. It is not unusual for complaints to the Ombudsman's Office to take many months or years to be finalized. Many prisoners are simply not in custody long enough to see 
a complaint through to completion. In October 1998, a man complained to the Ombudsman's Office about the Melbourne Custody Centre saying it had no natural light, poor ventilation, no fresh air or access to the natural environment, and that he witnessed a person being assaulted by other prisoners and the police did not come to the assistance of the victim (Ombudsman letter, 2000). The Ombudsman's Office replied in a letter 20 months later advising that the police were doing their best under difficult circumstances. I came to know of this matter as the prisoner brought the Ombudsman's letter to me and asked me to explain its contents, as he could not understand what it was about. After some confusion, it was established that the complaint had been made when he was serving an earlier sentence, but that he had since been released, but returned to custody. As far as the man was concerned the delayed response was now irrelevant - he screwedup the letter and threw it in the bin as he stormed out of the prison library saying: "That was last sentence!"

A question is raised at this point as to if this is a situation of benign inefficiency or malignant bad faith. A way to explore this question is to look at the Free Call service operated by the Ombudsman's Office, which allows prisoners to call and make complaints free of charge. This service was not well advertised, but word leaked out to prisoners at Barwon Prison in August 2007. Five prisoners took the opportunity to call the Ombudsman's Office to make a complaint about the operation of the phone system in relation to a pre-recorded message that is played at the start of all calls made by prisoners.

For a prisoner to place a number on their phone access account they have to submit a Phone Request Form, which is checked against a list of prohibited numbers by the prison's intelligence officer who is called the Collator. A number is prohibited if someone has asked Corrections Victoria not to allow calls to be made to that number from prisoners or a particular prisoner. If the number is not prohibited then the form is returned to prisoner's accommodation unit or some other location and an Officer telephones the person and explains who they are and that prisoner so and so has requested that their number be placed on their phone access account. The Officer confirms the name, the address and number of the person and their relationship to the prisoner. The Officer asks if the person is willing to receive calls from the prisoner. If the person agrees, then they are told that the calls are monitored and recorded, and they are not allowed to divert the calls or to engage in conference calls. The person is asked if they understand all this and if they agree to all of these 
conditions. If they agree, then the number is placed on the prisoner's phone access account as being verified. When a prisoner makes a call a recorded message plays and it says:

This phone call has originated from a prisoner at [name of specific institution] Prison. It is subject to monitoring and recording. It is unlawful to participate in a conference call or divert this call. If you do not want to accept this call please hang up now. If you understand the conditions of this call then proceed.

When this message was first introduced in 2007 prisoners made complaints saying:

- the tone in which the message is delivered is rude and threatening;

- $\quad$ it frightens children and confuses old people;

- the list of conditions and threats of 'illegality' are hard for people to understand;

- it sounds like the recipient is at risk of committing an offence;

- it is far too long;

- $\quad$ answering machine messages cannot be heard because of the length of the message, and the end of the message is often recorded on a person's answering machine. The prisoner is left saying "Hello, hello ..." until they realize that the silence must mean that they are talking to an answering machine;

- $\quad$ prisoners with families from non-English speaking backgrounds have been hanging up when the Anglo-Saxon voice starts threatening them;

- $\quad$ it is unreasonable to require people who have agreed to receive a call from a prisoner to hang up if they happen to be using modern technology like call diversion; how it is 'unlawful' for the person receiving the call to divert or participate in a conference call?;

- it is unreasonable to require people who have agreed to receive a call, to then have to understand the implications of the call as that relates to the telecommunications law and wire tapping;

- $\quad$ some legal secretaries and other professional services have refused to put prisoners through to their lawyers as that would be 'diverting a call' and that would be 'unlawful' according to the message; and 
- some family members worry or don't know if they can hand the phone to a visiting uncle or family friend who happens to be there when the prisoner calls. Is this diverting the call? Is this then a conference call?

Five prisoners made calls to the Free Call number of the Ombudsman's Office and made contemporaneous notes of those calls. The notes made about those calls in two cases need to be reproduced in full to explore the question of whether there is a benign inefficiency or malignant bad faith operating at the Ombudsman's Office. Although these calls were made in 2007, recent experience in 2014 demonstrates that nothing has changed.

\section{Craig (call made on 29 August 2007)}

Craig: I am a prisoner at Barwon and I want to make a complaint about the message that plays at the start of every phone call made by a prisoner.

Ombudsman's Office: Can I have your name and CRN.

Craig: Yes. [name and number given].

Ombudsman's Office: What is your complaint?

Craig: There is a message that plays at the start of each call a prisoner makes. There are two versions, one for legal calls and one for private calls, and these messages have recently been changed in the last 2 weeks. The tone of the message is rude and threatening. It frightens children and old people. The new conditions are hard to understand. It sounds like my people are being threatened with a prison offence. Prisoners with families from a non-English speaking background have been hanging up when the AngloSaxon voice starts threatening them.

Ombudsman's Office: Have you complained to the prison about it?

Craig: Yes I have and they say there is nothing they can do about it.

Ombudsman's Office: When did you complain? 
Craig: About two weeks ago.

Ombudsman's Office: We like to give agencies at least three weeks to get back to you with a formal response before we intervene.

Craig: I have got all the response I am going to get from them as I raised it with the officer who is responsible for the phone system.

Ombudsman's Office: Well we will have to ask the prison why they are playing a different message, because there will be good reasons why they have added new conditions.

Craig: Before you pre-judge the matter and accept that there are good reasons for them to add the conditions, my complaint is about the tone of the message, which is rude and threatening. It frightens children and old people. The new conditions are hard to understand. It sounds like my people are being threatened with a prison offence. Why they are playing the message is not the issue.

Ombudsman's Office: Has the new message affected you?

Craig: Yes it has. It puts my people off. They feel insulted and assaulted by the message. It took my mother a dozen calls before she could fully understand the message. By rights, she should have hung-up on me every time until she understood. If she does not understand or accept the conditions then it is unlawful for her to talk to me according to the message. This is rubbish.

Ombudsman's Office: We will make some inquiries with the relevant agency.

Craig: No. You need to listen to the message and see what you think yourself. If you were to call the Collator at Barwon, I am sure that he or she could email you the WAV files and you could hear them for yourself. It would be a simple matter.

Ombudsman's Office: We will make inquiries with the relevant agency in relation to why the message has been changed and the need for the message. 
Craig: No. I am complaining to you about the message, its tone, its rudeness, it is hard to understand, not why they are playing it. So will you listen to the message?

Ombudsman's Office: We will give the agency the opportunity to respond first.

Craig: Respond to what? I have their response already. I am complaining to you about the message, and I am asking will you listen to the message so you can hear it for yourself and judge my complaint on the evidence. Will you listen to the message?

Ombudsman's Office: It may not be me as someone else may look at it, or it may be someone else.

Craig: Who is the someone else?

Ombudsman's Office: Someone from the agency concerned.

Craig: What is the point in that?

Ombudsman's Office: They can say why the message is being played.

Craig: No. My complaint is not about why it is being played. You are not listening to me. I am complaining that the tone of the message is rude and threatening. It frightens children and old people. The new conditions are hard to understand. It sound like my people are being threatened with a prison offence. What has that go to do with why they say they are playing the message and what they think about it?

Ombudsman's Office: We will get the agency to ...

Craig: Will you listen to the message?

Ombudsman's Office: I can't guarantee that.

Craig: Will you or someone from your office at least try to listen to it? 
Ombudsman's Office: We will get the agency to ...

Craig: Let's say I complained that they had smashed a piece of my property. Would you not want to view that evidence?

Ombudsman's Office: Someone would look at it, yes.

Craig: No. Would someone from your office look at it?

Ombudsman's Office: The appropriate person would look at it.

Craig: Who is that?

Ombudsman's Office: I can’t say.

Craig: We are going around in circles here aren't we. Will you get back to me?

Ombudsman's Office: Yes we will.

Craig: Thank you. Goodbye. ${ }^{2}$

These notes show that in Craig's call the Ombudsman's Office:

- $\quad$ attempted to redefine the complaint relation to the reason why the message was played so that it was a strawman that could easily be knocked over if they had good reasons. The reasoning for the message was never the complaint as Craig tried very hard to make clear;

- $\quad$ prejudged the situation by saying there would be a good reason for changing the message and for it being played - not that this was ever the complaint, and this is prejudging and redefining in one; and

- $\quad$ refused to listen to the evidence, i.e., the message, but rather would allow Corrections to say why the message was played - which of course was never the complaint.

The following example involves another prisoner who has been assigned a pseudonym to protect his identity. 


\section{David (call made on 30 August 2007)}

David: I am a prisoner from Barwon as you can tell by the message.

Ombudsman's Office: I don't listen to those messages.

David: Well that is exactly what I am ringing up about.

Ombudsman's Office: Can I ask your name?

David: My name is David.

Ombudsman's Office: I don't know if I can help.

David: I need to talk to you about the phone message.

Ombudsman's Office: I don't handle complaints, I am just the person inbetween the phone, I will put you on to someone.

David: Is this the number to call?

Ombudsman's Office: [Different person] Hello Ombudsman's Office.

David: I am David. I am ringing about the pre-recorded phone message.

Ombudsman's Office: Have you talked to management about it?

David: Yes I have.

Ombudsman's Office: Have you written to management about it?

David: No.

Ombudsman's Office: For me to process your complaint, you have to exhaust all other avenues of complaint within the agency.

David: I have talked to them about it and I can't get a decent answer other than it is "state wide" as if that excuses the message. The message is upsetting 
for my mother and for my children, because there are references to prison charges and a requirement that they must understand the conditions before continuing, but the conditions are confusing.

Ombudsman's Office: Have you written to management yet?

David: No, but they know it is a problem as half the unit has complained about it.

Ombudsman's Office: Yes, I am aware of other complaints, but you need to write to the CEO of Corrections before I can deal with it. Do you know if it's a message generated by the prison itself or by an outside agency?

David: I don't know. No one can tell me anything about this problematic message. Have you listened to the message to see what prisoners are complaining about?

Ombudsman's Office: I don't have to, but what you need to do is write to the CEO and if you are not happy with that explanation, then write to us with copies of all the correspondence and if there is enough complaints then we will look more deeply into the matter. I am not saying that your complaint is not valid, just that there is a procedure that requires you to exhaust all avenues of complaint within the agency before complaining to us.

These notes show that in David's call the Ombudsman's Office:

- $\quad$ attempted to deflect dealing with the complaint by requiring first verbal complaints, and then written complaints to Corrections and that all of these avenues of complaint needed to be travelled down, one after the other, until there was no resolution (this suggested path would take between 8-12 months);

- wanted fruitless avenues of complaint pursued and then the complaints process would be considered to see if that process was handled right, not if the message was problematic. It was never David's complaint that Corrections were not handling his complaint properly; and

- $\quad$ refused to listen to the evidence, i.e., the message, but rather would look at how Corrections handled the complaint about the message. 
The Free Call number for prisoners to contact the Ombudsman's Office is promoted by that Office as an example of how accessible and responsive the Office is to complaints from prisoners. For prisoners, however, the reality is that the Free Call number is used as a device to discourage prisoners from making complaints. Prisoners are fobbed-off, talked around in circles and have their complaint re-framed and handballed out of bounds during the call and they hang up thinking: 'What's the point of complaining?'

\section{CONCLUSION}

Before I answer the question posed by this paper as to if the Ombudsman's Office in Victoria is an effective accountability mechanism that is faithful to its role in the rule of law, or if it is a forlorn hope, it will be helpful to summarize the evidence in this matter so far.

The disadvantaged and vulnerable social and personal circumstances of prisoners are common, as is the difficulty of an individual person defending oneself against an abuse of power. It is also common ground that professional and government assistance for disadvantaged people is in a funding and availability free-fall. The need for administrative accountability and oversight of the actions of the powerful when vulnerable people are involved should never be in question.

As an example of administrative accountability and oversight, the Ombudsman's Office in Victoria, Australia is an agency of accountability. The role of such an agency is a vital one for the rule of law, and if an abuse of power that victimises vulnerable people is not to go unchecked, such an agency should be accessible and responsive to complaints from prisoners.

I have argued that when seen in terms of the official investigation and substation rates of prisoner complaints, as an effective administrative accountability mechanism, the Ombudsman's Office in Victoria, falls far short of international standards. As one example, in England and Wales, the Prisoners and Probation Ombudsman accepted for investigation 50 percent of the complaints made in 2010/11 (Seneviratne, 2012). As a pattern the Ombudsman in Victoria, accepts less than 1 percent of complaints for investigation. Moreover, the complaints accepted for investigation are often matters that are used as cannon fodder to be trivialised in the media. I have also shown that social justice NGOs and lawyers provided ample primary evidence of the ineffectiveness of the Ombudsman's Office, which has been accepted by the UNHCHR (Minogue v. Australia 2004). 
Finally, in two case studies it was shown that accessibility of the Ombudsman's Office through a free-call number was used to deflect prisoners' complaints by the Office:

- attempting to redefine the complaint away from the real issue being complained about, to a procedural issue;

- $\quad$ prejudging the situation by claiming there would be a good reason for the action taken by corrections;

- $\quad$ refusing to engage with documentary evidence which prisoners claimed illustrated the issue being complained about; and

- $\quad$ attempting to deflect dealing with the complaint by requiring a process that is inordinately long (between 8-12 months).

Effective accountability mechanisms overseeing corrections in Australia and beyond are a vital element in the rule of law. In the case of the Office of the Ombudsman Victoria, Australia, however, accountability amounts to little more than a forlorn hope.

\section{ENDNOTES}

1 As of 2013 these statistics are no longer gathered by Corrections Victoria as a costcutting exercise.

2 The Ombudsman's Officer never did get back to the author about this matter.

\section{REFERENCES}

Biondo, Sam (2002) "Letter from the Fitzroy Legal Service to the UNHCHR" December 6.

Carl, Sabine (2013) "Prisoner welfare, human rights and the North Rhine-Westphalia prison ombudsman", Journal of Social Welfare and Family Law, 34(3): 365-377.

Department of Justice / Corrections Victoria (2010) Statistical Profile of the Victorian Prison System 2005-06 to 2009-10 - October.

Edney, Richard (2002) "Letter to the UNHCHR" - August 23.

Foucault, Michel (1980) Power/Knowledge: Selected Interviews and Other Writings, 1972-1977, in C. Gordon (ed.) and C. Gordon, L. Marshall, J. Mepham, and K. Soper (trans.), New York: Pantheon Books.

Foucault, Michel (1977) Language, Counter-Memory, Practice: Selected Essays and Interviews, Donald F. Bouchard (ed.) Donald F. Bouchard and Sherry Simon (trans.), Ithaca: Cornell University Press.

Gutting, Garry (1994) The Cambridge Companion to Foucault, Cambridge (MA): Cambridge University Press. 
Herald Sun (2005) "Toy ban chipped" - February 8.

Kelly, Jeremy (2003) "Crims take the cake", Herald Sun - November 1.

Kuek, Gabriel (2002) "Letter to the UNHCHR" - June 11.

May, Todd (1993) Between Genealogy and Epistemology: Psychology, Politics, and Knowledge in the Thought of Michel Foucault, University Park (PA): The Pennsylvania State University Press.

Minogue, Craig (2011) "Is the Foucauldian Conception of Disciplinary Power Still at Work in Contemporary Forms of Imprisonment?, Foucault Studies, 11: 178-192.

Minogue, Craig (2009) "The Engaged Specific Intellectual: Resisting Unethical Prison Tourism and the Hubris of the Objectifying Modality of the Universal Intellectual", Journal of Prisoners on Prisons, 18(1\&2): 129-142.

Minogue, Craig (2005) "The Use of a Military Level of Force on Civilian Prisoners: Strip Searching, Urine Testing, Cell Extractions and DNA Sampling in Victoria", Alternative Law Journal, 30(4): 170-173.

Minogue, Craig (2003) "Excluding Prisoners from FOI in Victoria", Freedom of Information Review, 104(April): 26-30.

Minogue, Craig (2002) “An Insider's View: Human Rights and Excursions from the Flat Lands", in D. Brown and M. Wilkie (eds.), Prisoners as Citizens: Human Rights in Australian Prisons, Annandale (NSW): The Federation Press, pp. 196-212.Mottram, Murray (2001) "Does the watchdog have enough bite?", The Age Newspaper January 6.

Ombudsman Victoria (2007) Annual Reports 1998 to 2007, Office of the Ombudsman, Victoria.

Ombudsman Letter (2000) Letter dated July 17 (Ref: LP/057598).

Perry, B. W. (2000) Letter from the Ombudsman to C. Minogue dated July 3 (Ref: I 999051021$)$.

Seneviratne, Mary (2012) "Ombudsmen and Prisoner Complaints in the UK", Journal of Social Welfare and Family Law, 34(3): 339-356.

Smith, Cathy (2002) Letter from the Victorian Council of Social Services, to the UNHCHR - October 11.

Victorian Ombudsman (2014) Annual Report - September 3.

Victorian Ombudsman (2001) Annual Report.

\section{CASE LAW}

Minogue v Australia 2004 UNHCR 52 (11 November 2004).

Minogue v Williams (2000) Vol. 60 Administrative Law Decisions, p.366.

Minogue v Human Rights and Equal Opportunity Commission (1998) Vol. 166 Australian Law Reports, p.29; and at (1999) Vol. 57 Administrative Law Decisions, p.23.

Minogue v Human Rights and Equal Opportunity Commission [1998] Vol. 54 Administrative Law Decisions, p.389; and at (1998) Vol. 84 Federal Court Reports, p.438. 


\section{ABOUT THE AUTHOR}

Craig W. J. Minogue (www.craigminogue.org) has survived in prison since 1986. He earned a BA (Hons) in 2005 and in 2012 he was awarded a research based $\mathrm{PhD}$ in Applied Ethics, Human and Social Sciences. Craig assists fellow prisoners with equitable access to the courts, educational programs and health services. He designed a program of training and wrote a training manual for Health and Infection Control Peer Educators in Victoria's prison system, and he currently works as such an educator. Craig has over 45 publications in the fields of educational practice, philosophy, literature, criminal law, human rights and prison issues. He also creates art when he can and he has a number of works hanging in public buildings in Melbourne. Craig can be contacted by email at craig2016@bigpond.com or by mail at the following address:

Craig Minogue

Locked Bag 3

Castlemaine Victoria

Australia 3450 